\title{
MIR106A Pre-miRNA
}

National Cancer Institute

\section{Source}

National Cancer Institute. MIR106A Pre-miRNA. NCI Thesaurus. Code C82751.

MIR106A pre-miRNA is an oligoribonucleotide that is encoded by the human MIR106A gene and has a role in the regulation of gene expression. 